\title{
Trophic interactions among the heterotrophic components of plankton in man-made peat pools
}

\author{
Michał NIEDŹWIECKI, Małgorzata ADAMCZUK, ${ }^{*}$ Tomasz MIECZAN \\ Department of Hydrobiology, University of Life Sciences in Lublin, B. Dobrzańskiego str. 37, 20-262 Lublin, Poland \\ *Corresponding author: malgorzata.adamczuk@up.lublin.pl
}

\begin{abstract}
Man-made peat pools are permanent freshwater habitats developed due to non-commercial man-made peat extraction. Yet, they have not been widely surveyed in terms of ecosystem functioning, mainly regarding the complexity of heterotrophic components of the plankton. In this study we analysed distribution and trophic interrelations among heterotrophic plankton in man-made peat pools located in different types of peatbogs. We found that peat pools showed extreme differences in environmental conditions that occurred to be important drivers of distribution of microplankton and metazooplankton. Abundance of bacteria and protozoa showed significant differences, whereas metazooplankton was less differentiated in density among peat pools. In all peat pools stress-tolerant species of protozoa and metazoa were dominant. In each peat pool five trophic functional groups were distinguished. The abundance of lower functional trophic groups (bacteria, heterotrophic nanoflagellates (HNF) and ciliates feeding on bacteria and HNF) was weakly influenced by environmental drivers and was highly stable in all peat pool types. Higher functional trophic groups (naupli, omnivorous and carnivorous ciliates, cladocerans, adult copepods and copepodites) were strongly influenced by environmental variables and exhibited lower stability. Our study contributes to comprehensive knowledge of the functioning of peat bogs, as our results have shown that peat pools are characterized by high stability of the lowest trophic levels, which can be crucial for energy transfer and carbon flux through food webs.
\end{abstract}

Key words: Microbial loop; classical food chain; metazoa; Crustacea; peatbog.

Received: October 2016. Accepted: February 2017.

\section{INTRODUCTION}

Food webs in aquatic ecosystems function via the channelling of energy and flux of materials among diverse assemblages of organisms organized into two chains: the microbial loop and the classical trophic chain. The microbial loop is composed of bacteria and heterotrophic protists (Azam et al., 1983), and the role of these communities consists in recovering carbon and nutrients and transferring them to higher trophic levels of the classical trophic chain. Distinct components of the microbial loop influence one another in predator-prey relations and are also influenced by metazooplankton, which are components of the classical grazing chain (Sanders and Wickham, 1993; Gasol et al., 1995; Bec et al., 2003). Likewise, distinct trophic levels of metazooplankton within the classical food chain affect one another and are directly influenced by planktivorous fish and indirectly by piscivorous fish. These complex predator-prey relations influence species composition and abundances of major components of food chains and in this way can alter their trophic relationships and stability. Countless possible relations between distinct levels of microbial and classical food chains have been described in marine and freshwater ecosystems (Beaver and Crisman, 1982; Güde, 1986;
Gilbert et al., 1998; Wickham, 1995a, 1995b; Jürgens and Jeppesen, 2000). However, available information on diversity and correlations among components of food chains in other types of aquatic ecosystems, including humic wetlands, is particularly scarce. Humic wetlands have higher concentration of organic matter (OM) in comparison to other aquatic ecosystems, and large quantities of $\mathrm{OM}$ are in relatively recalcitrant dissolved form, mostly derived from moss decomposition (Rydin and Jeglum, 2013). As organic matter of low nutritive value is decomposed through a sequence of physical, chemical and biological processes, interactively coupled group of organisms must be recognised to properly evaluate the rate of organic matter regeneration in wetlands. Microbial loop may have significant role in transferring energy from allochtonous OM to metazoplankton, thus food web in these ecosystems may be largely sustained by bacterial production (Jones, 1992). Only a few studies around the world have surveyed plankton food webs in these systems, generally concluding that trophic interactions affecting food webs are dictated by a conjunction of specific morphology and abiotic features of wetlands (Sharma and Bhattarai, 2005; Druvietis et al., 2010; Quiroga et al., 2013). Peatbogs are wetlands with the capacity to accumulate dead organic matter (peat), in most cases from 
slowly decomposing plants. For centuries, peat has been used as a heating fuel and for a wide variety of non-fuel purposes, including horticulture (Robertson, 1993; Cruickshank et al., 1995). As a result of non-commercial, small-scale extraction of peat, distinctive water bodies have developed. Owing to biological succession, they have semi-natural features enhancing the biodiversity of peatbogs (Beadle et al., 2015). Pools are critical habitats for biodiversity in natural peatlands. They serve as habitats for specific plant communities, foraging sites for amphibians, and breeding habitats for some species of arthropod (Larson and House, 1990; Poulin et al., 1999; Mazerolle, 2005). Man-made peat pools have specific physical and chemical properties, including carbon budget, $\mathrm{pH}$, conductivity, and nutrient concentrations. Pools situated within an ombrotrophic peat profile are characterized by low $\mathrm{pH}$, low levels of primary production and nutrients and high levels of dissolved organic matter Pools that have any sort of minerotrophic input may differ from this pattern and have higher levels of $\mathrm{pH}$ and conductivity.

Currently, creating of artificial pools on peatland is a common tool used in restoration of degraded peatlands (Armstrong et al., 2009). However, the ecological status of these man-made pools is almost unknown. As environmental conditions can influence the structure and composition of planktonic communities in lake ecosystems and trophic relations between them (Persson, 1999; Adamczuk et al., 2015), we hypothesized that man-made peat-pools differ in heterotrophic assemblages according to their characteristic environmental constraints. An additional objective of the study was to estimate the stability of heterotrophic plankton as food web components in order to better understand the effect of environmental drivers on the functioning of food webs in man-made peat pools.

\section{METHODS}

\section{Study area}

We estimated biocenotic structures of man-made peat pools from peatbogs located in Polesie National Park (east-central Poland). The park is part of the West Polesie Biosphere Reserve protected under the Ramsar Convention as an important wetland site with valuable natural features. It covers 9764.31 ha, and peatbogs account for about $41 \%$ of its area (Radwan, 2002). The peatbogs in Polesie National Park are one of a very few groups of peatbogs in Europe formed during the Elsterian glaciation. Six man-made peat pools located on three types of peatbogs were selected for the study: two peat pools located on the carbonate fen Bagno Bubnów (hereafter CF), two peat pools located on the transitional peatland JelinoKrugłe Bagno (TP), and two peat pools located on the high moor peatland Moszne (HM). CF (51 $23^{\prime} 05.4^{\prime \prime} \mathrm{N}$, $\left.23^{\circ} 08^{\prime} 07.8^{\prime \prime} \mathrm{E}\right)$ is located in the eastern part of the park in a basin on chalk bedrock. It is a rare type of base-rich peatbog with small patches of purple moor grass meadows and poor-fen vegetation. TP $\left(51^{\circ} 24^{\prime} 05.9^{\prime \prime} \mathrm{N}\right.$, $\left.23^{\circ} 09^{\prime} 06.9^{\prime \prime} \mathrm{E}\right)$ lies in the western part of the major complex of the park and is probably fed by both precipitation and groundwater. $\mathrm{HM}\left(51^{\circ} 27^{\prime} 29.83^{\prime \prime} \mathrm{N}, 23^{\circ} 07^{\prime} 30.69^{\prime \prime} \mathrm{E}\right)$ is situated at the centre of the major complex of the park and is fed mainly by precipitation. The areas of the peat pits do not exceed $0.5 \mathrm{ha}$, and their depth reaches a maximum of 2 metres. They represent different vegetation types. The vegetation of TP is heavily dominated by Sphagnum cuspidatus and Utricularia sp., the vegetation of HM is dominated by Chara fragilis, and CF is colonized by Utricularia sp. and Potamogeton sp.

\section{Field sampling}

\section{Environmental parameters}

Environmntal variables were measured monthly from April to November 2013-2014. Temperature, dissolved oxygen (DO), electrical conductivity (EC) and $\mathrm{pH}$ were determined in situ with a YSI 556 MPS multiparametric probe. Other environmental variables were measured in the laboratory: total suspended solids (TSS), total organic carbon (TOC), biochemical oxygen demand (BOD) and chemical oxygen demand (COD) using a PASTEL UV spectrophotometer (Secomam, France); total phosphorus $\left(\mathrm{P}_{\text {tot }}\right)$ and dissolved ortho-phosphorus $\left(\mathrm{P}-\mathrm{PO}_{4}\right)$ with a Schimadzu UV-1610 spectrophotometer (by the molybdate method after mineralization with a mixture of $\mathrm{HNO}_{3}$ and $\mathrm{H}_{2} \mathrm{SO}_{4}$ ); and nitrate nitrogen $\mathrm{N}-\mathrm{NO}_{3}$ by the sodium salicylate method. Total solids (TS) were estimated according to NREL Laboratory Analytical Procedures (LAP) (Sluiter et al., 2008). Chlorophyll $a$ (chl-a) was determined spectrophotometrically after extraction with ethanol (Yentsch and Menzel, 1963).

\section{Bacteria and protozoa}

From each peat pool three replicate samples were collected once a month from April to November 2013-2014. The abundance of bacteria and HNF were determined with DAPI - 4'6-diamino-2-phenylindole (Porter and Feig, 1980). A $10-\mathrm{mL}$ volume of water was preserved in formaldehyde to a final concentration of $2 \%$ and kept in darkness at $4^{\circ} \mathrm{C}$. Preparations were made within $24 \mathrm{~h}$ after sampling. Sub-samples of $2 \mathrm{~mL}$ were condensed on polycarbonate filters $(0.2 \mu \mathrm{m}$ pore size $)$ dyed with Irgalan black and enumerated by epifluorescence microscope. Ciliata communities were investigated using a $5 \mathrm{~L}$ planktonic sampler; three replicate samples of volume $0.5 \mathrm{~L}$ were fixed with Lugol's solution $(0.2 \%$ final concentration). Densities of ciliates were determined with an in- 
verted microscope by the settling chamber technique: 50 $\mathrm{mL}$ of sample was sedimented for at least $24 \mathrm{~h}$ and half of the bottom of the chamber was counted at $300 \times$ magnification (Utermöhl, 1958).

\section{Metazoa}

From each peat pool, double samples of a 5 L volume were collected and pooled to reduce heterogeneity in metazooplankton distribution and sampling variability, so that the final volume of a sample measured $10 \mathrm{~L}$. Each sample was taken in three replications. Samples were sieved through a $40 \mu \mathrm{m}$ mesh net and initially fixed with Lugol's solution. Cladocera and Copepoda species were classified and counted using a Sedgewick-Rafter chamber.

\section{Data processing}

Differences in environmental conditions and density between the three peat pool types were analysed by oneway ANOVA. No significant differences between pools located on the same peatbog were revealed for any abiotic and biotic variable. Therefore, pools located on each peatbog were considered as grab samples and values of all variables were averaged per sampling date. All variables met the assumption of ANOVA without transformation. All data were previously analysed for distribution and homocedasticity of variables using normality and equal variance tests. In all the cases, the significance level used was 0.05 . Tukey's post hoc comparisons (at $\mathrm{P}<0.05$ ) were used to compare means when significant differences were found. Spearman's rank correlation coefficients were used to evaluate the correlation of all pairs of environmental variables to determine which variables were inter-correlated. Trophic groups were distinguished on the basis of feeding habits of taxa. Feeding habits were evaluated with the use of Foissner and Berger (1996), Dussart and Defaye (2001), Dumont and Negrea (2002). The coefficient of variation $(\mathrm{CV})$ was used to quantify the temporal stability of each trophic group: CV $(\%)=100 \sigma /$ mean, where $\sigma$ is the standard deviation. $\mathrm{CV}$ was computed on raw data of density of each trophic group.

In order to assess the influence of different environmental variables on the overall diversity as well as abundance of taxonomic and trophic groups, a Redundancy Analysis (RDA) was performed using raw data. This choice of linear ordination model was justified by the narrow range of the data (previously assessed by DCA with a gradient length $<2$ standard deviations). Automatic forward selection of environmental variables, performed by the Monte Carlo permutation test (999 permutations), was used to determine the most important variables (Lepš and Šmilauer, 2003). On the resultant plot, the arrows representing environmental variables indicate the direction of maximum change of that variable, and the length of each arrow is proportional to the rate of change. The ordination analyses were performed in CANOCO 4.5 for Windows.

\section{RESULTS}

\section{Environmental parameters}

Statistically significant differences between the peat pools were found for $\mathrm{pH}, \mathrm{TOC}$, chl-a, $\mathrm{P}-\mathrm{PO}_{4}, \mathrm{COD}, \mathrm{BOD}$ $(\mathrm{P}<0.01)$, EC, and TS $(\mathrm{P}<0.05)$ (Tab. 1). The lowest $\mathrm{pH}$ values were recorded in $\mathrm{HM}$, while values closer to 7 (neutral $\mathrm{pH}$ ) were observed in CF. TOC, chl- $a, \mathrm{P}^{-\mathrm{PO}_{4}}$, and COD had the lowest values in $\mathrm{CF}$ and the highest in HM, whereas BOD was lowest in TP and highest in HM. Conductivity and TS content were lowest in TP and highest in CF. Tukey post hoc comparisons detected the smallest differences between $\mathrm{CF}$ and $\mathrm{TP}$, which differed in $\mathrm{pH}, \mathrm{EC}$, and TSS $(\mathrm{P}<0.05)$. $\mathrm{CF}$ and $\mathrm{HM}$ exhibited significant differences in $\mathrm{pH}, \mathrm{EC}, \mathrm{TOC}$, chl-a, $\mathrm{P}-\mathrm{PO}_{4}, \mathrm{COD}$, and $\mathrm{BOD}$ $(\mathrm{P}<0.05)$. TP and HM differed in TSS, TOC, chl-a, $\mathrm{P}^{-} \mathrm{PO}_{4}$, $\mathrm{COD}$, and BOD $(\mathrm{P}<0.05)$ (Tab. 1). Some environmental variables showed significant inter-correlations. $\mathrm{pH}$ showed positive correlations with TS, EC, ${\mathrm{N}-\mathrm{NH}_{4}}_{4}$ (Spearman's rank correlation, $r$ range: 0.34 to $0.43, \mathrm{P}<0.05$ ), and negative correlations with TOC, COD and BOD (Spearman's rank correlation, $r$ range: -0.34 to $-0.43, \mathrm{P}<0.05$ ). There were also inter-correlations between above variables, including TS and conductivity (Spearman's rank correlation, $\mathrm{r}=-0.47, \mathrm{P}=0.004$ ), and $\mathrm{TS}$, TOC, COD, BOD (Spearman`s rank correlation, $r$ range: 0.46 to 0.89 , $\mathrm{P}<0.001)$. Other group of inter-correlating variables were $\mathrm{DO}, \mathrm{EC}$ and biogenes, including $\mathrm{N}-\mathrm{NO}_{3}, \mathrm{P}^{-\mathrm{PO}_{4}}$, and $\mathrm{P}_{\text {tot }}$ (Spearman's rank correlation, $\mathrm{r}$ range: 0.46 to 0.89 , $\mathrm{P}<0.001) . \mathrm{N}^{-\mathrm{NO}_{3}}$ correlated with TOC, COD, and BOD (Spearman's rank correlation, $\mathrm{r}$ range: 0.73 to 0.74 , $\mathrm{P}<0.01)$. Another group of correlates were chlorophyll-a correlating negatively with $\mathrm{pH}$ (Spearman's rank correlation, $\mathrm{r}=-0.44, \mathrm{P}=0.009$ ), and positively with $\mathrm{N}^{-\mathrm{NO}_{3}}$, TSS, TOC, COD, and BOD (Spearman's rank correlation, $r$ range: 0.52 to $0.89, \mathrm{P}<0.01$ ). Among this group of correlates, TSS showed significant correlation with COD $(\mathrm{r}=0.34, \mathrm{P}=0.048)$.

\section{Heterotrophic plankton - composition, abundance and relation to environmental parameters}

Microbial plankton components showed significant differences in density between the peat pools (ANOVA, $F=7.493-15.994, \mathrm{P}<0.001$ ), reaching the lowest values in $\mathrm{HM}$ and the highest in CF. Mean abundance of bacteria ranged from $0.669 \pm 0.173$ cells $10^{6} \mathrm{~mL}^{-1}$ to $2.75 \pm 0.813$ cells $10^{6} \mathrm{~mL}^{-1}$, and showed significant differences between CF and TP and between CF and HM (Tukey posthoc comparisons, $\mathrm{P}<0.01$ in both cases). HNF reached from $1 \pm 0.5$ in $\mathrm{HM}$ to $2.87 \pm 1.03$ cells $10^{3} \mathrm{~mL}^{-1}$ in $\mathrm{CF}$, and 
differed significantly between all pairs of peat pools (Tukey post hoc comparisons, $\mathrm{P}<0.01$ for $\mathrm{CF}-\mathrm{TP}$ and $\mathrm{CF}$ HM, $\mathrm{P}<0.05$ for TP-HM). The highest species richness of ciliates was observed in CF (20 taxa) with dominant Cinetochilum margaritaceum, while TP had the lowest species richness, with 13 taxa observed, of which Strombidium sp. was dominant. In HM, 18 taxa were found and Paramecium bursaria was dominant. Mean density of ciliates varied from $19 \pm 1.19$ to $34 \pm 12$ ind $\mathrm{mL}^{-1}$, and differed between CF and HM (Tukey post-hoc comparisons, $\mathrm{P}<0.01$ ) and between CF and TP (Tukey post-hoc comparisons, $\mathrm{P}<0.05)$. Among metazooplankton, Cladocera showed greater differentiation in taxonomic composition between the peat pools, ranging from 13 species with dominant Chydorus sphaericus in HM and 15 species with dominant Ceriodaphnia quadrangula in TP to 22 species with dominant Alona costata in CF. Copepoda were represented by 6-7 species, with dominant Mesocyclops leuckartii in HM and TP and Thermocyclops crassus in CF. Crustacean plankton showed significant differentiation in density between the peat pools (ANOVA, $F=$ 3.325-6.833, $\mathrm{P}<0.05$ ). Both Cladocera and Copepoda displayed the lowest densities in HM and the highest in TP. Mean density of Cladocera ranged from $8 \pm 7$ ind. $\mathrm{dm}^{-3}$ to $162 \pm 155$ ind. $\mathrm{dm}^{-3}$, while the mean density of Copepoda varied from $7 \pm 5$ ind. $\mathrm{dm}^{-3}$ to $295 \pm 464$ ind. $\mathrm{dm}^{-3}$. Tukey post-hoc comparisons of Crustacea density between peat pools showed that HM was distinct from TP $(\mathrm{P}<0.01$ for Copepoda and Cladocera) and $\mathrm{CF}(\mathrm{P}<0.05$ for both groups of Crustacea). RDA showed a clear influence of environmental variables on densities of heterotrophic plankton.
All axes accounted for $40.3 \%$ of the total variance in the relationship between environment and density of planktonic communities and distinctly separated peat pools. Variables that significantly explained the variance in density of heterotrophic plankton were $\mathrm{pH}$ (Monte Carlo permutation test, $\lambda=0.07 ; F=3.78 ; \mathrm{P}=0.003)$, $\mathrm{BOD}(\lambda=0.09$; $F=4.36 ; \mathrm{P}=0.003)$, DO $(\lambda=0.08 ; F=4.59 ; \mathrm{P}=0.004)$, Chl-a $(\lambda=0.05 ; F=2.8 ; \mathrm{P}=0.03)$, TS $(\lambda=0.03 ; F=2.14 ; \mathrm{P}=0.04)$, and $\operatorname{COD}(\lambda=0.02 ; F=1.4 ; \mathrm{P}=0.04)$. The first axis explained $36.1 \%$ of the total variance in the relationship between environment al variables and density of planktonic communities and was mostly influenced by Copepoda and DO and correlated with HM. The second axis explained $4.1 \%$ of the total variance in the relationship between environmental variables and density of planktonic communities and was positively correlated with $\mathrm{pH}$, bacteria, HNF, Cladocera, Ciliata and CF, and negatively with BOD, chl-a, TS and COD (Fig. 1).

\section{Functional trophic groups within heterotrophic plankton and their stability}

Analysis of the feeding habits of individual taxa within plankton communities made it possible to distinguish 5 functional trophic groups. The first two groups comprised bacteria (I) and HNF (II). Third group consisted of bacterivorous and HNF-feeding ciliates (IIIa) and naupli - larval stages of copepods (IIIb). The fourth group comprised omnivorous and predatory ciliates (IVa) preying on groups I-III and cladocerans (IVb) preying on groups I-IIIa. The fifth group consisted of omnivorous and

Tab. 1. Mean values ( \pm standard deviation) of environmental parameters of water in the peat pools. Abbreviations of chemical parameters are detailed in the text.

\begin{tabular}{|c|c|c|c|c|c|c|c|c|c|}
\hline & \multicolumn{3}{|c|}{ Mean values \pm standard deviation } & \multicolumn{3}{|c|}{ One-way ANOVA } & \multicolumn{3}{|c|}{ Tukey HSD } \\
\hline & $\mathrm{CF}$ & $\mathrm{TP}$ & HM & F & df & $\mathbf{P}$ & CF-TP & CF-HM & TP-HM \\
\hline $\mathrm{pH}$ & $7.04 \pm 0.51$ & $4.73 \pm 1.01$ & $4.65 \pm 1.17$ & 15.994 & 33 & 0.00001 & $\mathrm{P}<0.01$ & $\mathrm{P}<0.01$ & \\
\hline Temperature $\left({ }^{\circ} \mathrm{C}\right)$ & $15.12 \pm 4.09$ & $19.23 \pm 4.81$ & $17.93 \pm 5.18$ & 1.785 & 33 & 0.184 & & & \\
\hline Conductivity $\left(\mu \mathrm{S} \cdot \mathrm{cm}^{-1}\right)$ & $367 \pm 107.62$ & $19.58 \pm 6.86$ & $7.38 \pm 7.10$ & 7.629 & 33 & 0.002 & $\mathrm{P}<0.01$ & $\mathrm{P}<0.01$ & \\
\hline Dissolved oxygen $\left(\mathrm{mg} \cdot \mathrm{L}^{-1}\right)$ & $7.08 \pm 1.31$ & $7.73 \pm 2.16$ & $7.32 \pm 2.78$ & 0.001 & 33 & 0.999 & & & \\
\hline $\mathrm{TS}\left(\mathrm{mg} \cdot \mathrm{L}^{-1}\right)$ & $70.5 \pm 7.12$ & $11.45 \pm 9.64$ & $159.91 \pm 92.53$ & 3.658 & 32 & 0.037 & & & $\mathrm{P}<0.05$ \\
\hline $\mathrm{TSS}\left(\mathrm{mg} \cdot \mathrm{L}^{-1}\right)$ & $68.27 \pm 17.19$ & $137.79 \pm 33.39$ & $298.69 \pm 125.94$ & 7.230 & 31 & 0.0026 & $\mathrm{P}<0.05$ & & $\mathrm{P}<0.01$ \\
\hline $\mathrm{TOC}\left(\mathrm{mg} \cdot \mathrm{L}^{-1}\right)$ & $17.47 \pm 2.67$ & $21.32 \pm 3.09$ & $51.72 \pm 21.58$ & 14.843 & 33 & 0.00003 & & $\mathrm{P}<0.01$ & $\mathrm{P}<0.01$ \\
\hline chl-a $\left(\mu \mathrm{g} \cdot \mathrm{L}^{-1}\right)$ & $10.03 \pm 5.4$ & $42.69 \pm 24.50$ & $50.65 \pm 29.14$ & 12.845 & 33 & 0.0001 & & $\mathrm{P}<0.01$ & $\mathrm{P}<0.01$ \\
\hline $\operatorname{Ptot}\left(\mathrm{mg} \cdot \mathrm{L}^{-1}\right)$ & $0.13 \pm 0.09$ & $0.16 \pm 0.13$ & $0.58 \pm 0.26$ & 1.221 & 33 & 0.308 & & & \\
\hline $\mathrm{N}-\mathrm{NO}_{3}\left(\mathrm{mg} \cdot \mathrm{L}^{-1}\right)$ & $0.17 \pm 0.12$ & $0.62 \pm 0.58$ & $0.72 \pm 0.47$ & 2.844 & 33 & 0.73 & & & \\
\hline $\mathrm{N}-\mathrm{NH}_{4}\left(\mathrm{mg} \cdot \mathrm{L}^{-1}\right)$ & $0.18 \pm 0.15$ & $0.12 \pm 0.31$ & $0.39 \pm 0.44$ & 1.430 & 30 & 0.255 & & & \\
\hline $\mathrm{P}-\mathrm{PO}_{4}\left(\mathrm{mg} \cdot \mathrm{L}^{-1}\right)$ & $0.07 \pm 0.04$ & $0.050 \pm 0.036$ & $0.09 \pm 0.11$ & 8.231 & 33 & 0.001 & & $\mathrm{P}<0.01$ & $\mathrm{P}<0.01$ \\
\hline $\mathrm{COD}\left(\mathrm{mg} \mathrm{O}_{2} \cdot \mathrm{L}^{-1}\right)$ & $39.89 \pm 8.58$ & $46.11 \pm 10.10$ & $110.76 \pm 48.83$ & 12.058 & 33 & 0.0001 & & $\mathrm{P}<0.01$ & $\mathrm{P}<0.01$ \\
\hline $\mathrm{BOD}\left(\mathrm{mg} \mathrm{O}_{2} \cdot \mathrm{L}^{-1}\right)$ & $23.64 \pm 5.94$ & $27.97 \pm 4.64$ & $68.78 \pm 28.73$ & 14.776 & 33 & 0.00003 & & $\mathrm{P}<0.01$ & $\mathrm{P}<0.01$ \\
\hline
\end{tabular}

CF, carbonate fen; TP, transitional peatland; HM, high moor peatland; $d f$, degrees of freedom. 
carnivorous copepods preying on groups IIIa-IV. Taxonomical characteristics and trophic relations between groups are presented in Tab. 2 and Fig. 2. Groups I-II showed significant inter-habitat differences in density (ANOVA, $F=16.694-60.825, \mathrm{P}<0.00001$ ), and differenced between CF and TP and between CF and HM (Tukey post-hoc comparisons, $\mathrm{P}<0.05$ ). Groups IIIa, IIIb and IVa showed weaker differences (ANOVA, $F=3.535-$ 8.489, $\mathrm{P}<0.03$ ) and differed only between $\mathrm{CF}$ and $\mathrm{HM}$ (Tukey post-hoc comparisons, $\mathrm{P}<0.05$ ), whereas groups $\mathrm{IVb}$ and $\mathrm{V}$ (ANOVA, $F=2.902-4.540, \mathrm{P}<05$ ) differed significantly between TP and HM (Tukey post-hoc comparisons, $\mathrm{P}<0.05$ ). In RDA analysis, all axes accounted for $41.1 \%$ of the total variance in the relationship between environment and density of trophic groups. However, influence of environmental variables on I-IIIa groups was weak. The Monte Carlo permutation test showed the significance of four variables: DO $(\lambda=0.08, F=4.04$, $\mathrm{P}=0.009$ ), influencing mainly group $\mathrm{V}$, temperature $(\lambda=0.03, F=0.94, \mathrm{P}=0.013)$, primarily affecting groups $\mathrm{IIIb}$ and IVb, and TS $(\lambda=0.02, F=0.74, \mathrm{P}=0.023)$ and TSS $(\lambda=0.01, F=0.42, \mathrm{P}=0.034)$, influencing group IVa (Fig. 3). Values of CV showed that stability of densities of distinct functional trophic groups decreased along with level in food chain, with groups I-IIIa showing greater stability $(\mathrm{CV}=22 \%-65 \%)$ than the other functional groups $(\mathrm{CV}=60 \%-204 \%)$. Trophic groups showed the highest stability in HM (33\%-106\%), whereas in CF the lowest stability of trophic groups was observed (36\%-204\%).

\section{DISCUSSION}

Although peatlands occupy extensive areas in the northern hemisphere, information on the ecology of peat pools is rare (Rydin and Jeglum, 2013). The present study represents one of the very few studies on interactions among heterotrophic plankton in man-made peat pools. Our studies showed that peat pools displayed very different chemical features that were in phase with chemical conditions of surrounding peatlands, similarly to natural freshwater ecosystems (Ferencz, 2016). They also differed in abundances of bacteria, protozoa and metazoa. Despite differences in bacteria densities, the abundances of these organisms were typical for humic water bodies within Sphagnum bogs, generally characterized by low abundance of these groups (Druvietis et al., 1998, 2010; Taipale et al., 2009). However, the bacterial abundances in the peat pools were much lower than those observed in other Sphagnum-dominated habitats, like hummocks and hollows (Langenheder et al., 2006: $1.39 \cdot 10^{6}$ cells $\mathrm{mL}^{-1}$; Quiroga et al., 2013: 6.2-11.1 $10^{6}$ cells $\mathrm{mL}^{-1}$ ) suggesting that although studied peat pools had anthropogenic origins, their biota were typical for natural water bodies in



Fig. 1. RDA biplots showing relationships between environmental variables and abundances of heterotrophic plankton in peat-pools. Peat pools are designated as follows: • carbonate fen (CF), $\boldsymbol{\bullet}$ transitional peatland (TP), $\boldsymbol{\Delta}$ high moor peatland (HM). 
peatlands. Densities of HNF shaped similarly to those reported in wetlands (Sinistro, 2009; Straskrábová et al., 2011). Their abundance was correlated with bacteria, a phenomenon often observed in aquatic ecosystems
(Simon et al., 1998; Gurung et al., 2000). Mean abundances of ciliates were similar to those observed in various peatbog ecosystems (Mieczan, 2009, 2010; Quiroga et al., 2013). The peat pools were colonized by stress-tol-

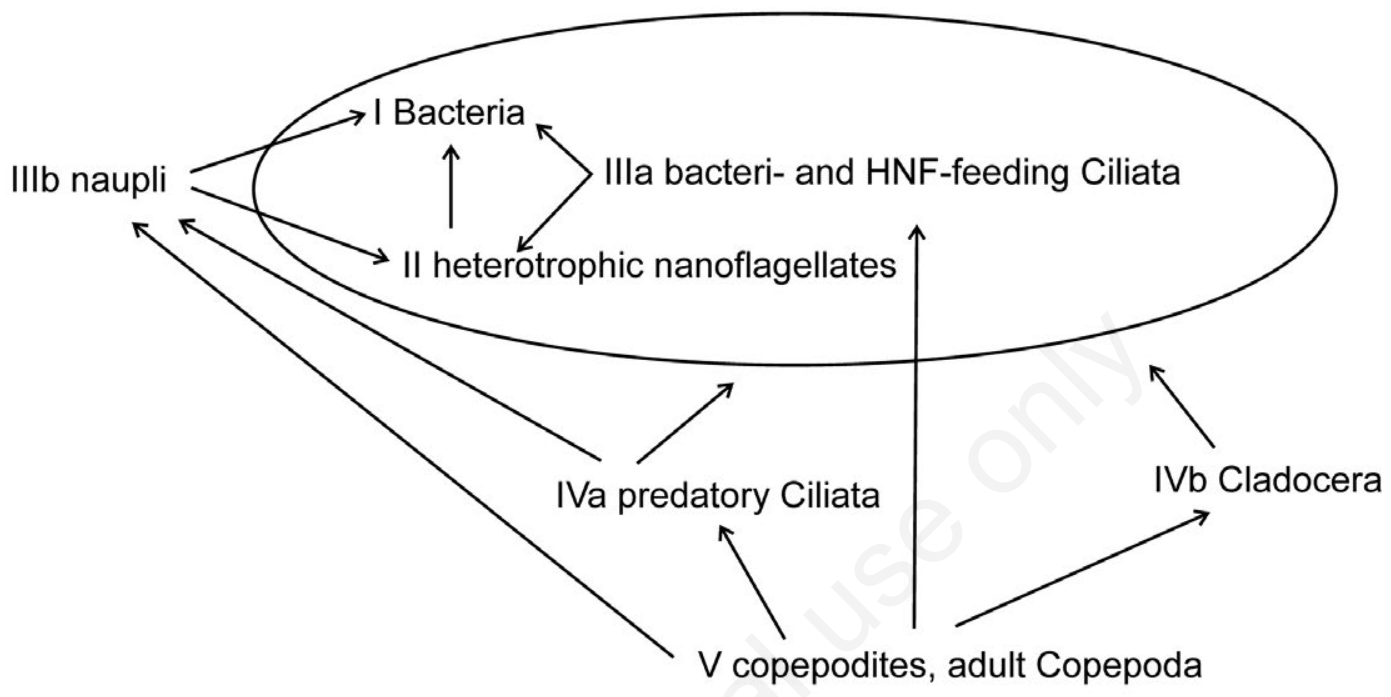

Fig. 2. Trophic relationships between functional trophic groups in peat pools. Meaning of trophic groups is detailed in Tab. 2 .

Tab. 2. Functional trophic groups of plankton communities in the man-made peat pools.

\begin{tabular}{|c|c|c|c|}
\hline $\begin{array}{l}\text { Functional } \\
\text { group }\end{array}$ & $\begin{array}{l}\text { Ecological } \\
\text { characteristics }\end{array}$ & $\begin{array}{l}\text { Trophic relations to } \\
\text { other functional groups }\end{array}$ & $\begin{array}{l}\text { Taxonomical } \\
\text { characteristics }\end{array}$ \\
\hline $\mathrm{I}$ & Bacteria & & - \\
\hline II & 28 & I & - \\
\hline IIIa & Bacteri- and HNF-vorous ciliates & I, II & $\begin{array}{l}\text { Aspidisca costata, Chilodonella uncinata, Cinetochilum mar- } \\
\text { garitaceum, Codonella cratera, Coleps spetai, Colpoda cucul- } \\
\text { lus, Drepanomonas revoluta, Holosticha pullaster, } \\
\text { Paramecium bursaria, Spirostomum ambigum, Strombidium } \\
\text { viride, Strombilidium } \mathrm{sp} \text {. }\end{array}$ \\
\hline $\mathrm{IIIb}$ & Naupli & I, II & - \\
\hline IVa & Omnivorous and carnivorous ciliates & I, II, III & $\begin{array}{l}\text { Amphileptus cleparedei, Coleps hirtus, Euplotes sp., Lacry- } \\
\text { maria olor, Paradileptus elephantinus, Prorodon sp., Spathid- } \\
\text { ium sensu lato, Stylonychia mytilus- Komplex }\end{array}$ \\
\hline $\mathrm{IVb}$ & Cladocerans & I, II, IIIa & $\begin{array}{l}\text { Acantholeberis curvirostris, Acroperus harpae, Alonella excisa, } \\
\text { Alonella exigua, Alona costata, Alona guttata, Alona interme- } \\
\text { dia, Alona quadrangularis, Alona rectangula, Alona rectangula } \\
\text { pulchra, Ceriodaphnia pulchella, Ceriodaphnia quadrangula, } \\
\text { Ceriodaphnia reticulata, Chydorus latus, Chydorus sphaericus, } \\
\text { Diaphanosoma brachyurum, Eurycercus lamellatus, } \\
\text { Macrothrix hirsuticornis, Macrothrix rosea, Moina brachiata, } \\
\text { Oxyurella tenuicaudis, Polyphemus pediculus, Pseudochydorus } \\
\text { globosus, Scapholeberis mucronata, Scapholeberis micro- } \\
\text { cephala, Simocephalus serrulatus, Simocephalus vetulus }\end{array}$ \\
\hline $\mathrm{V}$ & Adult copepods, copepodities & IIIa-IVb & $\begin{array}{l}\text { Cyclops strenuus, Eucyclops serrulatus, Macrocyclops albidus, } \\
\text { Macrocyclops fuscus, Mesocyclops leuckartii, Cryptocyclops } \\
\text { bicolor }\end{array}$ \\
\hline
\end{tabular}


erant species. The dominant species of Ciliata, i.e., $C$. margaritaceum, Strombidium sp., and P. bursaria, were eurytopic species common in a wide variety of aquatic ecosystems (Mori et al., 1998; Mieczan, 2009). Among cladocerans, C. sphaericus and C. quadrangula, which have a high tolerance to wide range of $\mathrm{pH}$ values (Flössner, 2000) and the ability to utilize detrital food sources (Gliwicz, 1977; Vijverberg and Boersma, 1997), were dominant in the acidic HM and TP. In the alkaline CF, the acid-sensitive $A$. costata (Havens, 1991; Walseng et al., $2003,2001)$ was dominant. All three species are widely encountered in different types of freshwater bodies (Duigan, 1992; Illyová and Némethová, 2005). Cladocerans present in peat pits were fairly eurytopic, as they also inhabit the macrophyte zone of hard-water lakes (Adamczuk, 2014). Similarly, Copepoda communities did not distinguish peat pools from other aquatic ecosystems, as $M$. leuckartii, dominant in the acidic peat pools, and $T$. crassus, dominant in the alkaline peat pools, are widely distributed in European freshwater bodies of many other types (Nilssen and Wærvågen, 2000). Both of these species are planktonic (Ueda and Reid, 2003), but they occasionally occur in small water bodies or in the littoral zone of lakes (Adamczuk, 2013).

The environmental variables taken together accounted for $40.3 \%$ of the total variance in abundance of food chain components, indicating that their distribution gradient cor- responds to changes in the environment. Biochemical and chemical oxygen demand, indicating amount of organic compounds, as well as other environmental parameters potentially indicative of resource subsidy for microbial loop components, were highest in the acidic pool, and lowest in the alkaline pool. Nonetheless, microbial loop components displayed the reverse pattern of densities diminishing along with $\mathrm{pH}$ decreases. Thus, $\mathrm{pH}$ occurred to be the strongest explanatory variable of variation in the density of microbial loop components. Positive correlations between abundances of microbial loop components and $\mathrm{pH}$ have also been reported in lake ecosystems (Yannarell and Triplet, 2004; Lindström et al., 2005; Gaedke and Kamjunken, 2006). Resource subsidy is considered one of the most important factors influencing food web functioning (bottom-up versus top-down control). However, negative correlations between components of microbial loop and resource subsidies and positive correlations between their densities and $\mathrm{pH}$ may suggest that the microbial loop components were controlled by water $\mathrm{pH}$ rather than resource availability in the peat pools. Additionally, negative $\mathrm{pH}-\mathrm{BOD}$ and $\mathrm{pH}-\mathrm{COD}$ correlations suggested that low $\mathrm{pH}$ indirectly inhibited the decay of organic matter by its direct influence on the density of microbial loop components. This conclusion was also supported by negative correlations between $\mathrm{pH}$ and TOC, chl-a, and TS as well correlations of the second axis with

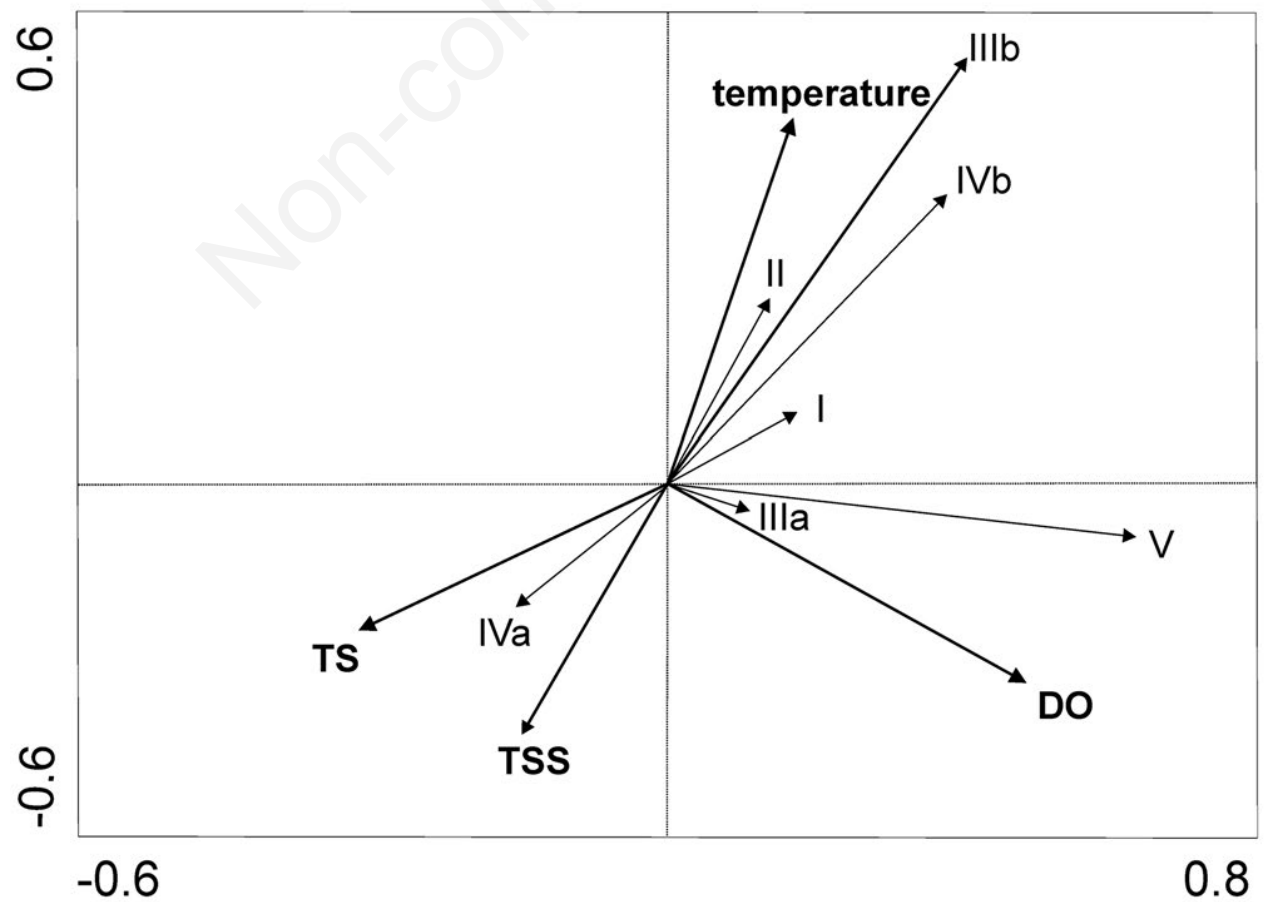

Fig. 3. RDA biplots showing relationships between environmental variables and biomasses of functional trophic groups in peat pools. Meaning of trophic groups is detailed in Tab. 2. Abbreviations of chemical parameters are detailed in the text. 
these parameters in RDA. pH also influenced the distribution of cladoceran communities. The influence of $\mathrm{pH}$ on Cladocera has also been shown in studies in lake ecosystems, with the conclusion that low $\mathrm{pH}$ coincides with decreased abundances of these animals (Nilssen and Sandoy, 1990; Kurbatova, 2005; Nevalainen et al., 2011). Cladocera are components of the lowest trophic level in the classical food web and function as intermediaries between the microbial and classical food chains (Agasild et al., 2012). Thus, $\mathrm{pH}$, through its direct effect on cladocerans, influenced higher trophic levels of the classical food chain. Copepoda density was correlated with DO concentrations. The crucial influence of DO concentration on successful development of Copepoda has been observed in both freshwater and brackish ecosystems (Tinson and Laybourn-Parry, 1985; Roman et al., 1993). Densities of heterotrophic plankton showed significant differences among peat pools, reaching the lowest densities in acidic peat pool and the highest densities in alkaline peat pools. Nonetheless, despite lowest density, heterotrophic plankton showed the highest stability in the acidic peat pools. I and II trophic groups (bacteria and HNF) were less influenced by environmental variables, and that was probably conducive to the stability of these groups. In the same way, group IIIa (bacterivorous and HNF-feeding ciliates) also showed resistance to environmental variables that coincided with their high stability. Higher trophic groups (naupli, omnivorous and carnivorous ciliates, cladocerans, copepodites and adult copepods) proved to be highly vulnerable to environmental variables, including DO, temperature, TS and TSS, and were less stable. In general, stability is thought to be mainly influenced by biodiversity (expressed as taxonomic richness) in plant and animal communities (Hector et al., 2010; Downing et al., 2014). However, Steiner (2005) found significant relationships between $\mathrm{CV}$ values and environmental variables in pond ecosystems. In the studied peat pools, we found similar relations but only for components of the classical food chain. Some papers have reported that in freshwater bodies stability of communities is linked to productivity, because it decreases with increasing system enrichment (Steiner, 2005) and eutrophication (Hautier et al., 2014). As the trophic status of peat pools and other humic water bodies differs from trophic statuses non-humic waters, the stability of food web components in these ecosystems is undoubtedly correlated with different environmental variables specific to this type of habitats.

\section{CONCLUSIONS}

Recently, man-made peat pools creating by drain blocking have been common restoration tool, however knowledge on the ecology of man-made pools is limited, especially in the domain of heterotrophic plankton. The present characterization of distribution and structure of heterotrophic plankton in correlation with environmental variables represents the first survey of the complete heterotrophic plankton food web from peat pools. In our studies, we found that the peat pools had different assemblages of food web components with respect to species composition, abundance, biomass, and distribution of dominant species. Despite these differences, food web components showed similar patterns of stability that showed inverse correlation with trophic level of organisms. Our studies deepen insight into the structure and functioning of artificial peat pools as surrogates for natural ecosystems with regard to trophic relations among heteroplanktonic organisms.

\section{ACKNOWLEDGMENTS}

This work was financed under project 2012/05/B/ NZ8/01263 by the National Science Centre, Poland. We acknowledge the editor and three anonymous reviewers, whose valuable comments improved the draft of the manuscript.

\section{REFERENCES}

Adamczuk M, 2013. The effect of habitat complexity on the contribution of some littoral-benthic Cladocera to the pelagic food web. Mar. Freshwater Res. 64:1049-1057.

Adamczuk M, 2014. Niche separation by littoral-benthic Chydoridae (Cladocera, Crustacea) in a deep lake-potential drivers of their distribution and role in littoral-pelagic coupling. J. Limnol. 73:490-501.

Adamczuk M, Mieczan T, Nawrot D, Rechulicz J, 2015. Indirect effect of environmental factors on interactions between microbial and classical food webs in freshwater ecosystems. Ann. Limnol.-Int. J. Lim. 51:49-58.

Agasild H, Zingel P, Nõges T, 2012. Live labeling technique reveals contrasting role of crustacean predation on microbial loop in two large shallow lakes. Hydrobiologia 684:177-187.

Armstrong A, Holden J, Kay P, Foulger M, Gledhill S, McDonald AT, Walker A, 2009. Drain-blocking techniques on blanket peat: a framework for best practice. J. Environ. Manage 90:3512-3519.

Azam F, Fenchel T, Field JG, Gray JS, Mayer-Reil LA, Thinstad F, 1983. The ecological role of water-column microbes in the sea. Mar. Ecol. -Prog. Ser. 10:257-263.

Beadle JM, Brown LE, Holden J, 2015. Biodiversity and ecosystem functioning in natural bog pools and those created by rewetting schemes. WIREs Water 2:65-84.

Beaver JR, Crisman TL, 1982. The trophic response of ciliated protozoans in freshwater lakes. Limnol. Oceanogr. 27: 246-253.

Bec A, Desvilettes C, Véra A, Lemarchand C, Fontvieille D, Bourdier G, 2003. Nutritional quality of a freshwater heterotrophic flagellate: trophic upgrading of its microalgal diet for Daphnia hyaline. Aquat. Microb. Ecol. 32:203-207. 
Cruickshank MM, Tomlinson RW, Bond D, Devine PM, Edwards CJW, 1995. Peat extraction, conservation and the rural economy in Northern Ireland. Appl. Geogr. 15:65-383.

Downing AL, Brown BL, Leibold MA, 2014. Multiple diversity-stability mechanisms enhance population and community stability in aquatic food webs. Ecology 95:173-184.

Duigan CA, 1992. The ecology and distribution of the littoral freshwater Chydoridae (Branchiopoda, Anomopoda) of Ireland, with taxonomic comments on some species. Hydrobiologia 241:1-70.

Dumont HJ, Negrea SV, 2002. Introduction to the class Branchiopoda. Guides to the identification of the microinvertebrates of the continental waters of the world. Backhuys Publishers, Leiden: 397 pp.

Dussart BH, Defaye D, 2001. Introduction to the Copepoda. Guides to the identification of the microinvertebrates of the continental waters of the world. Backhuys Publishers, Leiden: $334 \mathrm{pp}$.

Druvietis I, Springe G, Urtane L, Klavins M, 1998. Evaluation of plankton communities in small highly humic bog lakes in Latvia. Environ. Int. 24:595-602.

Druvietis I, Springe G, Briede A, Kokorīte I, Parele E, 2010. A comparative assessment of the bog aquatic environment of the Ramsar Site of Teiči Nature Reserve and North Vidzeme Biosphere Reserve, Latvia. Mires Peat 6:19-41.

Ferencz B, 2016. Role of hydrological factors in shaping water chemistry of small flow-through Polish lake. Envi. Earth Sci. 75:1-9.

Flössner D, 2000. [Die Haplopoda und Cladocera (ohne Bosminidae) Mittleeuropas].[Book in German]. Backhuys Publishers, Leiden: 428 pp.

Foissner W, Berger H, 1996. A user-friendly guide to the ciliates (Protozoa, Ciliophora) commonly used by hydrobiologists as bioindicators in rivers, lakes, and waste waters, with notes on their ecology. Freshwater Biol. 35: 375-482.

Gaedke U, Kamjunke N, 2006. Structural and functional properties of low-and high-diversity planktonic food webs. J. Plankton Res. 28:707-718.

Gasol JM, Simons AM, Kalff J, 1995. Patterns in the top-down versus bottom-up regulation of heterotrophic nanoflagellates in temperate lakes. J. Plankton Res. 17:1879-1903.

Gilbert D, Amblard C, Bourdier G, Francez AJ, 1998. The microbial loop at the surface of a peatland: structure, functioning and impact of nutrients inputs. Microb. Ecol. 35:89-93.

Gliwicz ZM, 1977. Food size selection and seasonal succession of filter feeding zooplankton in an eutrophic lake. Ekol. Pol. 17:179-225.

Güde H, 1986. Loss processes influencing growth of planktonic bacterial populations in Lake Constance. J. Plankton Res. 8:795-810.

Gurung TB, Nakanishi M, Urabe J, 2000. Seasonal and vertical difference in negative and positive effects of grazers on heterotrophic bacteria in Lake Biwa. Limnol. Oceanogr. 45:1689-1696.

Havens KE, 1991. Summer zooplankton dynamics in the limnetic and littoral zones of a humic acid lake. Hydrobiologia 215:21-29.

Hautier Y, Seabloom EW, Borer ET, Adler PB, Harpole WS, Hillebrand H, Lind EM, MacDougall AS, Stevens CJ, Bakker JD, Buckley YM, Chu C, Collins SL, Daleo P,
Damschen EI, Davies KF, Fay PA, Firn J, Gruner DS, Jin VL, Klein JA, Knops JMH, La Pierre KJ, Li W, McCulley RL, Melbourne BA, Moore JL, O'Halloran LR, Prober SM, Risch AC, Sankaran M, Schuetz M, Hector A, 2014. Eutrophication weakens stabilizing effects of diversity in natural grasslands. Nature 508:521-525.

Hector A, Hautier Y, Saner P, Wacker L, Bagchi R, Joshi J, Scherer-Lorenzen M, Spehn EM, Bazeley-White E, Weilenmann M, Caldeira MC, Dimitrakopoulos PG, Finn JA, Huss-Danell K, Jumpponen A, Mulder CPH, Palmborg C, Pereira JS, Siamantziouras ASD, Terry AC, Troumbis AYM, Schmid B, Loreau M, 2010. General stabilizing effects of plant diversity on grassland productivity through population asynchrony and overyielding. Ecology 91:2213-2220.

Jones RI, 1992. The influence of humic substances on lacustrine planktonic food chains. Hydrobiologia 229:73-91.

Kurbatova SA, 2005. Response of microcosm zooplankton to acidification. Biol. Bull. 32:85-92.

Illyová M, Némethová D, 2005. Long-term changes in cladoceran assemblages in the Danube floodplain area (SlovakHungarian stretch). Limnologica 35:274-282.

Jürgens K, Jeppesen E, 2000. The impact of metazooplankton on the structure of the microbial food web in a shallow, hypertrophic lake. J. Plankton Res. 22:1047-1070.

Langenheder S, Lindström ESM, Tranvik LJ, 2006. Structure and function of bacterial communities emerging from different sources under identical conditions. Appl. Environ. Microb. 72:212-220.

Larson DJ, House NL, 1990. Insect communities of Newfoundland bog pools with emphasis on the Odonata. Can. Entomol. 122:469-501.

Lepš J, Šmilauer P, 2003. Multivariate analysis of ecological data using CANOCO. Cambridge University Press, Cambridge: $283 \mathrm{pp}$.

Lindström ES, Kamst-Van Agterveld MP, Zwart G, 2005. Distribution of typical freshwater bacterial groups is associated with $\mathrm{pH}$, temperature, and lake water retention time. Appl. Environ. Microb. 71:8201-8206.

Mazerolle MJ, 2005. Peatlands and green frogs: a relationship regulated by acidity? Ecoscience 12:60-67.

Mieczan T, 2009. Ciliates in Sphagnum peatlands: vertical micro-distribution, and relationships of species assemblages with environmental parameters. Zool. Stud. 48:33-48.

Mieczan T, 2010. Vertical microzonation of testate amoebae and ciliates in peatbog waters in relation to physical and chemical parameters. Pol. J. Ecol. 58:729-740.

Mori G, Mattioli M, Madoni P, Ricci N, 1998. The ciliate communities of different habitats of Lake Massaciuccoli (Tuscany): Species composition and distribution. Ital. J. Zool. 65:191-202.

Nevalainen L, Luoto TP, Levine S, Manca M, 2011. Modern and pre-industrial age distributions of Cladocera in Italian and Swiss alpine lakes. Hydrobiologia 676:173-185.

Nilssen JP, Sandoy S, 1990. Recent lake acidification and cladoceran dynamics: surface sediment and core analyses from lakes in Norway, Scotland and Sweden. Philos. T. R. Soc. B. 327:299-309.

Nilssen JP, Wærvågen SB, 2000. Superficial ecosystem similarities vs autecological stripping: the 'twin species' Mesocyclops leuckarti (Claus) and Thermocyclops oithonoides 
(Sars) - seasonal habitat utilisation and life history traits. J. Limnol. 59:79-102.

Persson L, 1999. Trophic cascades: abiding heterogeneity and the trophic level concept at the end of the road. Oikos 85:385-397.

Porter KG, Feig YS, 1980. The use of DAPI for identifying and counting aquatic microflora. Limnol. Oceanogr. 25:943-948.

Poulin M, Rochefort L, Desrochers A, 1999. Conservation of bog plant species assemblages: assessing the role of natural remnants in mined sites. Appl. Veg. Sci. 2:169-180.

Quiroga MV, Unrein F, Garraza GG, Küppers G, Lombardo R, Marinone MC, Marque SM, Vinocur A, Mataloni G, 2013. The plankton communities from peat bog pools: structure, temporal variation and environmental factors. J. Plankton Res. 35:1234-1253.

Radwan S, 2002. Polesie National Park - monograph. Morpol Publ., Lublin: 272 pp.

Robertson RA, 1993. Peat, horticulture and environment. Biodivers. Conserv. 2:541-547.

Roman MR, Gauzens AL, Rhinehart WK, White JR, 1993. Effects of low oxygen waters on Chesapeake Bay zooplankton. Limnol. Oceanogr. 38:1603-1614.

Rydin H, Jeglum JK, 2013. The biology of peatlands. 2nd ed. Oxford University Press, Oxford: 423 pp.

Sanders RW, Wickham SA, 1993. Planktonic protozoa and metazoa: predation, food quality and population control. Aquat. Microb. Ecol. 7:197-223.

Sharma BK, Bhattarai S, 2005. Hydrobiological analysis of a peat bog with emphasis on its planktonic diversity and population dynamics in Bumdeling Wildlife Sanctuary, eastern Bhutan. Limnology 6:183-187.

Simon M, Tilzer MM, Müller H, 1998. Bacterioplankton dynamics in a large mesotrophic lake: I. abundance, production and growth control. Arch. Hydrobiol. 143:385-407.

Sinistro R, 2009. Top-down and bottom-up regulation of planktonic communities in a warm temperate wetland. J. Plankton Res. 32:209-220.

Sluiter A, Hames B, Hyman D, Payne C, Ruiz R, Scarlata C, Sluiter J, Templeton D, Wolfe J, 2008. Determination of total solids in biomass and total dissolved solids in liquid process samples. Technical Report NREL/TP-510-42621,
Golden, CO National Renewable Energy Laboratory: 9 pp.

Steiner CF, 2005. Temporal stability of pond zooplankton assemblages. Freshwater Biol. 50:105-112.

Straskrábová V, Lakatos G, Keresztúri P, 2011. Bacterial community structure in the wetlands of Hortobágyi Nemzeti Park (Hungary). Transyv. Rev. Syst. Ecol. Res. 12:127-135.

Taipale S, Jones RI, Tiirola M, 2009. Vertical diversity of bacteria in an oxygen-stratified humic lake, evaluated using DNA and phospholipid analyses. Aquat Microb Ecol 55:1-16.

Tinson S, Laybourn-Parry J, 1985. The behavioural responses and tolerance of freshwater benthic cyclopoid copepods to hypoxia and anoxia. Hydrobiologia 127:257-263.

Ueda H, Reid JW, 2003. Copepoda: Cyclopoida, genera Mesocyclops and Thermocyclops. Guides to the identification of the microinvertebrates of the continental waters of the world. Backhuys Publ., Leiden.

Utermöhl H, 1958. [Zur vervollkommnung der quantitativen phytoplankton methodik].[Article in German]. Internat. Verein. Theoret. Ang. Limnol. Verh. 9:1-38.

Walseng B, Yan ND, Schartau AK, 2003. Littoral microcrustacean (Cladocera and Copepoda) indicators of acidification in Canadian Shield lakes. Ambio 32:208-213.

Wickham SA, 1995a. Trophic relations between cyclopoid copepods and ciliated protists: complex interactions link the microbial and classic food webs. Limnol. Oceanogr. 40: 1173-1181.

Wickham SA, 1995b. Cyclops predation on ciliates: species. specific differences and functional responses. J. Plankton Res. 17:1633-1646.

Vijverberg J, Boersma B. 1997. Long-term dynamics of smallbodied and large-bodied cladocerans during eutrophication of a shallow reservoir, with special attention for Chydorus sphaericus. Hydrobiologia 360: 233-242.

Yannarell AC, Triplett EW, 2004. Within- and between-lake variability in the composition of bacterioplankton communities: investigations using multiple spatial scales. Appl. Environ. Microbiol. 70:214-223.

Yentsch CS, Menzel DW, 1963. A method for the determination of phytoplankton chlorophyll and phaeophytin by fluorescence. Deep Sea Res. Oceanogr. Abstr. 10:221-231. 